\title{
Nutritional plans for boars
}

\section{Charles Kiefer ${ }^{1}$, Juarez Lopes Donzele ${ }^{2}$, Rita Flavia Miranda de Oliveira ${ }^{2}$, Liliane Suguisawa ${ }^{3}$, Jorge Murilo Suguisawa ${ }^{3}$, Ana Carolina Wider Marques ${ }^{3}$}

\author{
1 FAMEZ/UFMS. \\ 2 DZO/CCA/UFV. \\ ${ }^{3}$ Designer Genes Technologies - Brasil.
}

ABSTRACT - The objective of the present study was to evaluate nutritional plans for boars. Four hundred animals of 67 to 135 days of age and initial weight of $27.75 \pm 1.61 \mathrm{~kg}$ were distributed in a randomized block design with seven nutritional plans for boars $(9.0-8.0 ; 9.0-9.0 ; 10.0-9.0 ; 10.0-10.0 ; 11.0-10.0 ; 11.0-11.0$ and $12.0-11.0 \mathrm{~g} / \mathrm{kg}$ of digestible lysine from 67 to 107 days and from 108 to 135 days, respectively) with four repetitions and a control plan for barrows $(11.0-10.0 \mathrm{~g} / \mathrm{kg}$ of digestible lysine) with eight repetitions and ten animals each. Uncastrated male swine presented better feed conversion; however they showed a lower marbling degree in relation to barrows, regardless of the nutritional plan. The nutritional plan that corresponds to the sequence of $11.0-10.0 \mathrm{~g} / \mathrm{kg}$ of digestible lysine from the 67 to the 107 days and from the 108 to the 135 days, respectively, meets the nutritional needs of boars.

Key Words: amino acids, ideal protein, nutrition, performance, requirement

\section{Introduction}

It has been observed that, over the years, boars (uncastrated male swine) present higher efficiency in relation to the utilization of feed nutrients and carcass characteristics when compared with barrows (castrated male swine), regardless of the weight range evaluated (Xue et al., 1997). In Brazil, however, the slaughter of boars is prohibited by law in the terms of the article 121 of the RIISPOA (Regulation of Industrial and Sanitary Inspection of Animal Products), Decree 30,691 of 03/29/1952, modified by the Decree 1,255 of $06 / 25 / 1962$, because the adipose tissue of the carcass of these animals may present strong odor due to the presence of high levels of androstenone and skatole (Zamaratskaia et al., 2008a).

The levels of androstenone and eskatole in the fat of boars may range from 0.0 to $5.0 \mathrm{ppm}$ and 0.0 to $0.8 \mathrm{ppm}$ respectively, depending on the weight, sexual maturity, age and genotype (Bonneau et al., 1992). In turn, concentrations between 0.20 and $0.25 \mathrm{ppm}$ for skatole and above $0.5 \mathrm{ppm}$ for androstenone lead to sensory rejection of swine meat by consumers (Annor-Frempong et al., 1997).

With the advent of immunocastration, an alternative technique to the traditional surgical castration method for males, the problem of odor in the meat from boars was overcome. The principle of immunocastration is based on the suppression of GnRH, which, in turn, prevents the stimulus to the secretion of LH and FSH by the pituitary gland, thus reducing the development of the testicles and the synthesis of steroid hormones (Bauer et al., 2008; Pauly et al., 2009), including androstenone (Zamaratskaia et al., 2008b), primary responsible for the odor in the carcass.

However, the use of the immunocastration technique in Brazil is relatively recent and the lack of knowledge of the applicable nutritional standards for this category persists. Moreover, the nutritional strategies applied to the production of male swine for breeding may not be applicable in the nutrition of uncastrated male animals for slaughter. In this context, considering the lack of information on the nutritional strategies related to the protein feeding for swine that will be subjected to immunological castration, this study was conducted to evaluate nutritional plans for boars of high genetic potential, from 67 to 135 days of age.

\section{Material and Methods}

The experiment was conducted in the pig breeding farm Rancho Alegre, in the city of Campo Grande/MS, Brazil. Four hundred Duroc/Pietran $\times$ Large White/Landrace pigs - 320 boars and 80 barrows - of high genetic potential for deposition of protein in the carcass, with 67 days of age and initial weight of $27.75 \pm 1.61 \mathrm{~kg}$ were used.

The animals were housed in pens equipped with automatic feeders and nipple drinkers in a concrete floor facility. During the experimental period, the indoor thermal variations were daily monitored at 7,12 and $17 \mathrm{~h}$ through 
the use of a set of dry bulb, wet bulb and black globe thermometers installed in the center of the room. The registered values were converted into globe and humidity temperature index to characterize the thermal environment in which the animals were maintained.

The animals were distributed in randomized block design with seven nutritional plans for boars (9.0-8.0; 9.0-9.0; 10.0-9.0; 10.0-10.0; 11.0-10.0; 11.0-11.0 and $12.0-11.0 \mathrm{~g} / \mathrm{kg}$ of digestible lysine, from 67 to 107 days and from 108 to 135 days, respectively) and one nutritional plan for barrows (11.0-10.0 g/kg of digestible lysine in the same stages), with four repetitions for each nutritional plan of the uncastrated and eight repetitions for the castrated males, with ten animals per pen, which was considered the experimental unit. The initial weight of the animals was taken into account in the formation of the blocks.

The experimental diets for the stages from 67 to 107 days (Table 1) and from 108 to 135 days (Table 2) were prepared based on corn and soybean supplemented with minerals and vitamins to meet the nutritional requirements of the animals according to Rostagno et al. (2005) for all nutrients, except for digestible lysine.

The different levels of digestible lysine of the experimental diets were obtained from the inclusion of L-lysine $\mathrm{HCl}$ replacing kaolin. The aminoacidic relations between digestible lysine and the other essential amino acids were met in accordance with the ideal protein standard set by Rostagno et al. (2005). Feed and water were given ad libitum to the animals throughout the experimental period. The feed waste was daily collected from the floor, weighed and added to the leftovers of the feeder at the end of the experiment.

The animals were weighed at the beginning of the experiment (67 days of age), at 107 and 135 days of age (end of the experiment) to determine the daily intake of feed and digestible lysine, the daily weight gain and the feed conversion ratio. The amount of digestible lysine per kilogram of weight gain was calculated from the results obtained for daily lysine ingestion minus the amount of daily lysine required for maintenance and divided by the observed daily weight gain. The daily lysine need for maintenance was calculated according to the equation: Lysine for maintenance $(\mathrm{g})=0.036 \times(\text { average weight })^{0.75}$, proposed by Wang \& Fuller et al. (1989).

At 135 days of age, the animals were subjected to carcass evaluation through in vivo ultrasonography. The ultrasonography device used was the ALOKA $500 \mathrm{~V}$, with a $12 \mathrm{Ba}$ acoustic probe with frequency of $3.5 \mathrm{Mhz}$. Silicone coupler that follows the rib vault, allowing a perfect coupling of the transducer with the bodies of the animals was used.
Soybean oil was used to avoid the presence of air between the probe and the skin. The carcass evaluation software used was the BIA PRO PLUS for Genetic Improvement, made available by the company Designer Genes Technologies. The depth of the muscle longissimus dorsi, the backfat thickness and the marbling degree of the longissimus dorsi (score 0 to 10) were measured. The software also performed adjustments of the muscle depth and backfat thickness corrected to a weight of $100 \mathrm{~kg}$. The percentage of lean meat in the carcass was determined through the equation proposed by Bridi \& Silva (2007), consisting of: $60-$ (backfat thickness $\times 0.58)+($ muscle depth $\times 0.10$ ).

The collected data were subjected to analysis of variance through the ANOVA procedure. The possible differences obtained between the nutritional plans for boars were evaluated through the Scott-Knott test. The averages of the variables obtained for barrows were compared with the averages of boars through the Dunnett test. The statistical analyses were performed with the use of the statistical software SAS (Statistical Analysis System, version 8.2) with the adoption of $\alpha=0.10$.

\section{Results and Discussion}

During the experimental period, the average values of air temperature, relative humidity, black globe temperature and globe and humidity temperature index corresponded to $28.4 \pm 2.5{ }^{\circ} \mathrm{C}, 91.8 \pm 9.8 \%, 28.9 \pm 2.6{ }^{\circ} \mathrm{C}$ and $79.7 \pm 3.3$, respectively. According to the results, it is possible to conclude that the environmental thermal conditions obtained during the execution of the experiment were close to the higher critical zone set for the category, which is $27^{\circ} \mathrm{C}$ and $90 \%$ for air temperature and relative humidity, respectively, according to Sampaio et al. (2004).

The nutritional plans did not affect $(\mathrm{P}>0.10)$ the daily feed intake of boars (Table 3 ). The observed results represent an indicative that pigs do not adjust the voluntary intake according to the concentration of lysine in the diet. This hypothesis is confirmed by the study of Owen et al. (1994), who evaluated diets containing a high variation of concentration of lysine $(5.0 ; 11.0)$ and able to regulate the voluntary intake based on the concentration of lysine in the diet. Similarly, Edmonds \& Baker (1987) found that the excess of lysine in the diet did not affect the feed ingestion by pigs.

No difference $(\mathrm{P}>0.10)$ was observed when comparing the performance of boars and barrows regarding the daily feed intake. This result differed form the observations published by Xue et al. (1995), who verified, from a literature 
Table 1 - Composition of experimental diets from 67 to 107 days

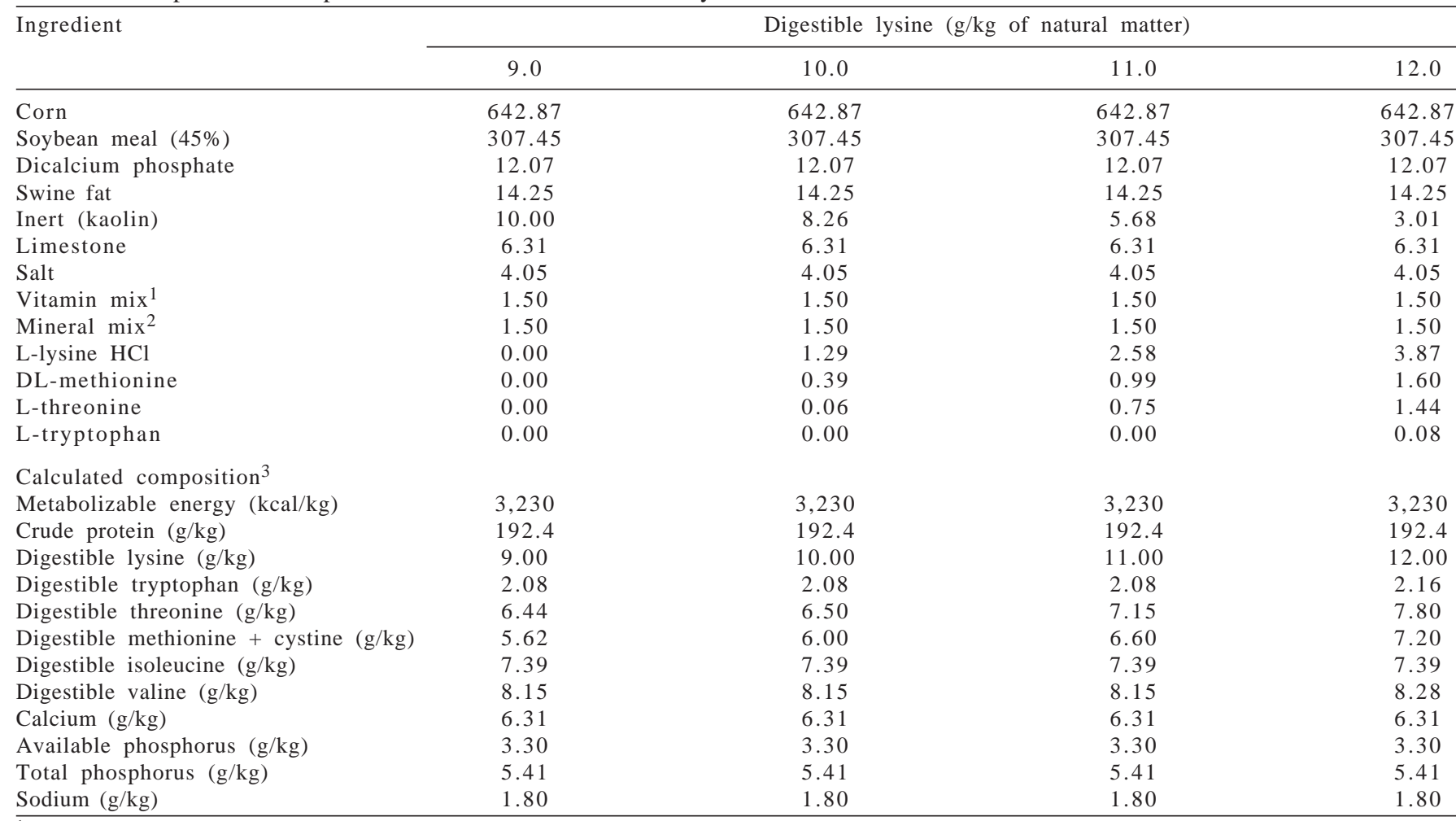

${ }^{1}$ Contents by kilogram of product: Fe - 100 g; Cu - 10 g; Co - 1.0 g; Mn - 40 g; Zn - 100 g; I - 1.5 g; Se - 0.3 g; excipient q.s. - 1,000 g.

${ }^{2}$ Contents by kilogram of product: vit. A - 6,000,000 UI; vit. D3 - 1,500,000 UI; vit. E - 15,000 UI; vit. B1 - 1.35 g; vit. B2 - 4.0 g; vit. B6 - 2.0 g; pantothenic acid - 10 g; vit. K3 - 1.5 g; nicotinic acid - 22 g; vit. B12 - 0.2 g; folic acid - 0.6 g; biotin - 0.08 g; choline - 100 g; excipient q.s. - 1,000 g.

3 Nutritional composition calculated according to information contained in Rostagno et al. (2005).

Table 2 - Composition of experimental diets from 108 to 135 days

\begin{tabular}{|c|c|c|c|c|}
\hline \multirow[t]{2}{*}{ Ingredient } & \multicolumn{4}{|c|}{ Digestible lysine ( $\mathrm{g} / \mathrm{kg}$ of natural matter) } \\
\hline & 8.0 & 9.0 & 10.0 & 11.0 \\
\hline Corn & 693.04 & 693.04 & 693.04 & 693.04 \\
\hline Dicalcium phosphate & 9.68 & 9.68 & 9.68 & 9.68 \\
\hline Swine fat & 10.34 & 10.34 & 10.34 & 10.34 \\
\hline Inert (kaolin) & 10.00 & 8.27 & 5.62 & 2.80 \\
\hline Limestone & 5.98 & 5.98 & 5.98 & 5.98 \\
\hline Mineral $\operatorname{mix}^{2}$ & 1.50 & 1.50 & 1.50 & 1.50 \\
\hline L-lysine $\mathrm{HCl}$ & 0.00 & 1.29 & 2.58 & 3.87 \\
\hline DL-methionine & 0.00 & 0.30 & 0.93 & 1.56 \\
\hline L-threonine & 0.00 & 0.14 & 0.84 & 1.55 \\
\hline L-tryptophan & 0.00 & 0.00 & 0.03 & 0.22 \\
\hline \multicolumn{5}{|l|}{ Calculated composition ${ }^{3}$} \\
\hline Digestible threonine $(\mathrm{g} / \mathrm{kg})$ & 5.90 & 6.03 & 6.70 & 7.37 \\
\hline Digestible methionine + cystine $(\mathrm{g} / \mathrm{kg})$ & 5.28 & 5.58 & 6.20 & 6.82 \\
\hline Digestible isoleucine $(\mathrm{g} / \mathrm{kg})$ & 6.70 & 6.70 & 6.70 & 6.70 \\
\hline Digestible valine $(\mathrm{g} / \mathrm{kg})$ & 7.50 & 7.50 & 7.50 & 7.59 \\
\hline Calcium $(\mathrm{g} / \mathrm{kg})$ & 5.51 & 5.51 & 5.51 & 5.51 \\
\hline Available phosphorus (g/kg) & 2.82 & 2.82 & 2.82 & 2.82 \\
\hline Total phosphorus (g/kg) & 4.85 & 4.85 & 4.85 & 4.85 \\
\hline Sodium $(\mathrm{g} / \mathrm{kg})$ & 1.70 & 1.70 & 1.70 & 1.70 \\
\hline
\end{tabular}

${ }_{1}$ Contents by kilogram of product: Fe - 100 g; Cu - 10 g; Co - 1.0 g; Mn - 40 g; Zn - 100 g; I - 1.5 g; Se - 0.3 g; excipient q.s. - 1,000 g.

${ }^{2}$ Contents by kilogram of product: vit. A - 6,000,000 UI; vit. D3 - 1,500,000 UI; vit. E - 15,000 UI; vit. B1 - 1.35 g; vit. B2 - 4.0 g; vit. B6 - 2.0 g; pantothenic acid - 10 g; vit. K3 - 1.5 g; nicotinic acid - 22 g; vit. B12 - 0.2 g; folic acid - 0.6 g; biotin - 0.08 g; choline - 100 g; excipient q.s. - 1,000 g.

${ }^{3}$ Nutritional composition calculated according to information contained in Rostagno et al. (2005). 
Table 3 - Performance of boars according to the nutritional plans

\begin{tabular}{|c|c|c|c|c|c|c|c|c|}
\hline Category & $\begin{array}{l}\text { Nutricional } \\
\text { plan }\end{array}$ & $\begin{array}{l}\text { Initial } \\
\text { weight } \\
\text { (kg) }\end{array}$ & $\begin{array}{l}\text { Final } \\
\text { weight } \\
\text { (kg) }\end{array}$ & $\begin{array}{l}\text { Feed } \\
\text { intake } \\
\text { (g/day) }\end{array}$ & $\begin{array}{l}\text { Lysine } \\
\text { intake } \\
\text { (g/day)* }\end{array}$ & $\begin{array}{l}\text { Weight } \\
\text { gain } \\
\text { (g/day) }\end{array}$ & $\begin{array}{c}\text { Lysine intake } \\
\text { per kilogram } \\
\text { of weight gain }(\mathrm{g} / \mathrm{kg})^{*}\end{array}$ & $\begin{array}{l}\text { Feed } \\
\text { conversion } \\
\text { rate* }\end{array}$ \\
\hline $\mathrm{BO}$ & $1-9.0-8.0$ & 27.90 & 80.57 & 1.85 & $15.79 d$ & 787 & $19.15 d$ & $2.35 a$ \\
\hline $\mathrm{BO}$ & $2-9.0-9.0$ & 27.95 & 80.40 & 1.84 & $16.57 \mathrm{~d}$ & 785 & $20.26 \mathrm{~d}$ & $2.35 a$ \\
\hline $\mathrm{BO}$ & $3-10.0-9.0$ & 27.91 & 80.44 & 1.80 & $17.15 d$ & 785 & $20.94 c$ & $2.29 \mathrm{a}$ \\
\hline $\mathrm{BO}$ & $4-10.0-10.0$ & 28.22 & 82.05 & 1.83 & $18.34 \mathrm{c}$ & 805 & $21.91 \mathrm{c}$ & $2.28 \mathrm{a}$ \\
\hline $\mathrm{BO}$ & $5-11.0-10.0$ & 27.47 & 81.90 & 1.77 & $18.60 \mathrm{c}$ & 814 & $21.96 \mathrm{c}$ & $2.17 b$ \\
\hline $\mathrm{BO}$ & $6-11.0-11.0$ & 28.24 & 82.75 & 1.80 & $19.75 b$ & 815 & $23.29 b$ & $2.20 \mathrm{~b}$ \\
\hline $\mathrm{BO}$ & $7-12.0-11.0$ & 27.69 & 82.90 & 1.82 & $20.93 a$ & 825 & $24.48 a$ & $2.20 \mathrm{~b}$ \\
\hline BA & $8-11.0-10.0$ & 27.19 & 79.90 & 1.96 & 20.59 & 788 & 25.13 & 2.49 \\
\hline $\mathrm{P}$ value & & 0.997 & 0.844 & 0.818 & $<0.001$ & 0.972 & $<0.001$ & 0.058 \\
\hline \multicolumn{9}{|l|}{ Contrasts } \\
\hline $\mathrm{BO} \times \mathrm{BA}$ & $1 \times 8$ & 0.570 & 0.150 & 0.948 & $<0.001$ & 0.248 & $<0.001$ & 0.070 \\
\hline $\mathrm{BO} \times \mathrm{BA}$ & $2 \times 8$ & 0.848 & 0.358 & 1.000 & $<0.001$ & 0.217 & $<0.001$ & 0.066 \\
\hline $\mathrm{BO} \times \mathrm{BA}$ & $3 \times 8$ & 0.808 & 0.323 & 1.000 & $<0.001$ & 0.100 & $<0.001$ & 0.011 \\
\hline $\mathrm{BO} \times \mathrm{BA}$ & $4 \times 8$ & 0.839 & 0.332 & 0.650 & $<0.001$ & 0.188 & $<0.001$ & 0.008 \\
\hline $\mathrm{BO} \times \mathrm{BA}$ & $5 \times 8$ & 0.622 & 0.737 & 0.477 & $<0.009$ & 0.042 & 0.002 & 0.001 \\
\hline $\mathrm{BO} \times \mathrm{BA}$ & $6 \times 8$ & 0.838 & 0.693 & 0.477 & 0.019 & 0.088 & 0.003 & 0.004 \\
\hline $\mathrm{BO} \times \mathrm{BA}$ & $7 \times 8$ & 0.610 & 0.953 & 0.238 & 0.220 & 0.064 & 0.138 & $<0.001$ \\
\hline CV (\%) & & 4.48 & 4.58 & 6.03 & 6.10 & 6.27 & 4.64 & 4.53 \\
\hline
\end{tabular}

BO - boars; BA - barrows.

* Means of uncastrated males followed by different letters in the column differ $(\mathrm{P}<0.05)$ by Scott-Knott test.

review, higher feed intake by castrated male in comparison with uncastrated animals. Similarly, Dunshea et al. (2001), Pauly et al. (2008) and Pauly et al. (2009) verified that barrows presented higher feed intake in relation to boars. According to Weiler et al. (1996), the plasmatic level of testosterone and the feed intake are correlated in a negative manner, indicating that this may be the main factor limiting feed ingestion by boars. Such proposition was confirmed by Claus \& Weiler (1987), who verified a reduction of $25 \%$ in the feed intake by barrows after an application of testosterone. In the case of the present study, the unobserved difference in intake between barrows and boars may be related to the environmental temperatures registered during the execution of the research, often above the thermal comfort zone for this category.

On the other hand, the nutritional plans affected $(\mathrm{P}<0.01)$ the daily intake of lysine of the uncastrated male, which increased according to the increase in the concentration of lysine in the diet. A higher daily intake was observed for the group fed with the plan that contained $12.0-11.0 \mathrm{~g} / \mathrm{kg}$ of digestible lysine. Considering that there was no significant variation in the voluntary ingestion of feed related to the nutritional plans for barrows, the increase in the daily lysine intake is directly related to the concentration of digestible lysine of the experimental diets.

Furthermore, it was observed that barrows presented a higher daily digestible lysine intake $(\mathrm{P}<0.01)$ in comparison with boars, except for the group that was fed with the nutritional plan that contained 12.0-11.0 g/kg of digestible lysine. This result may be explained by the high concentration of digestible lysine in the diets to which the barrows were subjected, associated to the high intake pattern observed in this category.

No effect $(\mathrm{P}>0.10)$ of nutritional plans was observed on the daily weight gain of the boars. The comparison between the daily weight gain of barrows and boars showed that boars, fed with the nutritional plans containing 11.0-10.0; $11.0-11.0$ and $12.0-11.0 \mathrm{~g} / \mathrm{kg}$ of digestible lysine, presented higher daily weight gain than the castrated animals. The result obtained is consistent with other studies, such as those of Dunshea et al. (2001) and Pauly et al. (2008), and demonstrates the higher nutrients utilization efficiency of the weight gain diet by boars in relation to barrows. This fact may possibly be explained by the anabolic hormonal patterns of such animals.

Effect $(\mathrm{P}<0.01)$ of the nutritional plans was observed on the lysine intake per kilogram of weight gain of boars, which increased according to the increase in the concentration of lysine in the diet. Considering that the nutritional plans showed no significant variance on the voluntary feed intake and on the weight gain of boars, the increase in the intake of lysine per kilogram may be explained by the increase in the concentration of digestible lysine in the diets. Similarly, when comparing the intake of lysine per kilogram of weight gain between barrows and boars, it could be verified that barrows presented higher $(\mathrm{P}<0.01)$ intake in relation to the castrated male animals, except for the nutritional plan based on the levels $12.0-11.0 \mathrm{~g} / \mathrm{kg}$ of lysine. 
The nutritional plans affected $(\mathrm{P}<0.05)$ the feed conversion rate of uncastrated male. The animals fed the diets corresponding to the sequences of 11.0-10.0; $11.0-11.0$ and $12.0-11.0 \mathrm{~g} / \mathrm{kg}$ of digestible lysine presented the best results when compared with the other plans. The improvement observed in the feed utilization efficiency of the animals subjected to the nutritional plans consisting of the sequential levels of $11.0-10.0 ; 11.0-11.0$ and $12.0-$ $11.0 \mathrm{~g} / \mathrm{kg}$ digestible lysine may indicate that they meet the nutritional needs of boars fed with such diets better.

The nutritional plans provided a better $(\mathrm{P}<0.07)$ feed conversion to boars when compared with castrated animals. Considering this result, we can infer that the better conversion rate observed for boars is due to the direct hormonal effect on the protein anabolism and to the higher efficiency of nutrients utilization of the diets. A higher nutrient utilization efficiency of the diet for weight gain in boars in relation to castrated was also observed in studies conducted by Dunshea et al. (2001), Pauly et al. (2008) and Pauly et al. (2009).

The final weight of the boars was not affected $(\mathrm{P}>0.10)$ by the nutritional plans, which is consistent with the results observed for the daily weight gain of the animals based on the experimental diets. Likewise, no differences $(\mathrm{P}>0.10)$ were observed when comparing the final weight of barrows and boars.

The nutritional plans did not affect $(\mathrm{P}>0.10)$ muscle depth, muscle depth corrected to $100 \mathrm{~kg}$ of weight, marbling, fat thickness, fat thickness corrected to $100 \mathrm{~kg}$ or percentage of lean meat in the carcasses of boars (Table 4).
In the comparison of carcass characteristics of barrows and boars, no differences $(\mathrm{P}>0.10)$ were found between the categories for loin depth and loin depth corrected to $100 \mathrm{~kg}$. On the other hand, a difference $(\mathrm{P}<0.08)$ was verified between the averages obtained for castrated males and boars for the marbling degree of the muscle longissimus dorsi, in which the castrated male swine showed superiority in relation to the boars, regardless of the nutritional plan to which they had been subject. According to a review performed by Babol \& Squires (2005), the total fat content of the carcasses of swine consists of subcutaneous fat, inter and intramuscular fat, and peri and retroperitoneal, in which the boars present lower concentration of each of these types of fat deposition in relation to the castrated animals.

Considering that the intramuscular fat (marbling) has been associated to the water holding capacity, tenderness and succulence of swine meat (Wood et al., 2008), it is possible to conclude that the meat produced from boars that will be subjected to immunocastration may have affected their sensory characteristics in relation to castrated animals, regardless of the protein pattern of the diet to which they will be subjected.

A difference $(\mathrm{P}<0.06)$ was also observed in the backfat thickness between the boars fed with the nutritional plans with levels of $10.0-10.0$ and $11.0-11.0 \mathrm{~g} / \mathrm{kg}$ of digestible lysine in relation to the castrated animals. When comparing the backfat thickness corrected for $100 \mathrm{~kg}$ of weight, it was verified that boars presented a lower backfat thickness than barrows, except for those subjected to the nutritional

Table 4 - Carcass characteristics of boars according to nutritional plans

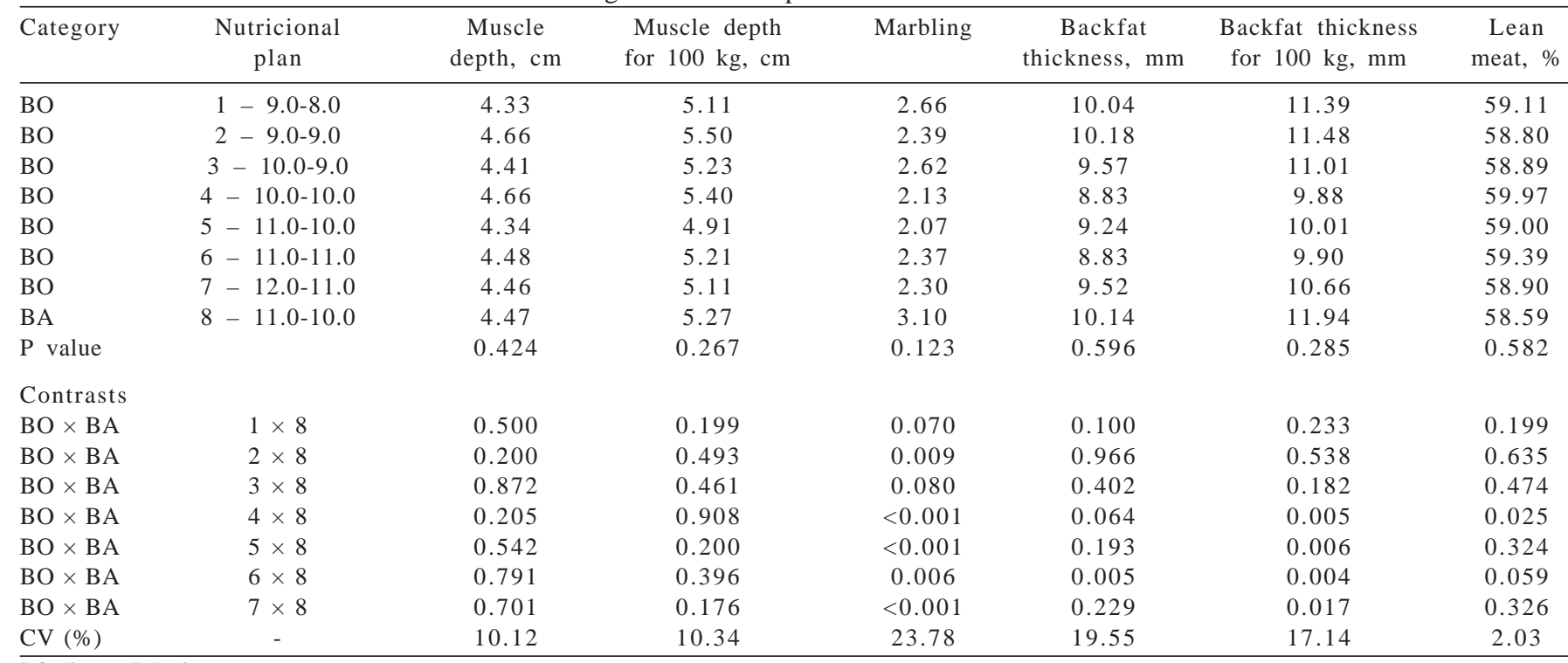


plans of levels 9.0-8.0; 9.0-9.0 and 10.0-9.0 $\mathrm{g} / \mathrm{kg}$ of digestible lysine.

Although no difference was observed in relation to the percentage of lean meat for boars between the nutritional plans, it was verified that boars subjected to the nutritional plans containing 10.0-10.0 and $11.0-11.0 \mathrm{~g} / \mathrm{kg}$ of digestible lysine presented higher percentage of lean meat $(\mathrm{P}<0.06)$ in comparison with barrows. The increase in the lean meat percentage observed in these nutritional plans is consistent with the results observed for backfat thickness. In turn, Xue et al. (1997) observed, from a literature review, lower values for backfat thickness and higher percentages of lean meat in boars in most of the researched studies, showing that these animals present a higher daily capacity of deposition of protein in the carcass in relation to castrated animals.

\section{Conclusions}

The nutritional plan that corresponds to the sequence of 11.0-10.0 g of digestible lysine per $\mathrm{kg}$ of feed from the 67 to the 107 days and from the 108 to the 135 days, respectively, meets the nutritional needs of uncastrated male swine. Boars present better feed conversion; however they showed lower marbling degree in relation to castrated swine, regardless of the nutritional plan.

\section{Acknowledgments}

The authors thank the owners of the Swine Breeding Farm Rancho Alegre and its manager Eleíza Moraes for the support provided to the execution of this study, the DGTBrasil for the evaluation of carcasses through ultrasonography and the CNPq for granting the postdoctoral fellowship to Charles Kiefer.

\section{References}

ANNOR-FREMPONG, I.E.; NUTE, G.R.; WHITTINGTON, F.W. et al. The problem of taint in pork. 1. Detection thresholds and odour profiles of androstenone and skatole in a model system. Meat Science, v.46, p.45-55, 1997.

BABOL, J.; SQUIRES, E.J. Quality of meat from entire male pigs. Food Research International, v.28, p.201-212, 1995.

BAUER, A.; LACORN, M.; DANOWSKI, K. et al. Effects of immunization against GnRH on gonadotropins, the GH-IGF-Iaxis and metabolic parameters in barrows. Animal, v.2, p.1215-1222, 2008.

BONNEAU, M.; LE DENMAT, M.; VAUDELET, J.C. et al. Contributions of fat androstenone and skatole to boar taint:
I. Sensory attributes of fat and pork meat. Livestock Production Science, v.32, p.63-80, 1992.

BRIDI, A.M.; SILVA, C.A. Métodos de avaliação de carcaça e da carne suína. Londrina: Midiograf, 2007. 97p.

CLAUS, R.; WEILER, U. Bowelteinflüsse auf das geschlechtsspezifische Wachstumsvermögen. Übersichten zur Tierernährung, v.15, p.301-316, 1987.

DUNSHEA, F.R.; COLANTONI, C.; HOWARD, K. et al. Vaccination of boars with a GnRH vaccine (Improvac) eliminates boar taint and increases growth performance. Journal of Animal Science, v.79, p.2524-2535, 2001.

EDMONDS, M.S.; BAKER, D.H. Aminoacids excesses for young pigs: effects of excess methionine, tryptophan, threonine or leucine. Journal of Animal Science, v.64, p.1664-1671, 1987.

OWEN, K.Q.; KNABE, D.A.; BURGOON, K.G. et al. Self-selection of diets and lysine requirements of growing-finishing swine. Journal of Animal Science, v.72, p.554-564, 1994.

PAULY, C.; SPRING, P.; O’DOHERTY, J.V. et al. Growth performance, carcass characteristics and meat quality of grouppenned surgically castrated immunocastrated (Improvac $®$ ) and entire male pigs and individually penned entire male pigs. Animal, v.3, p.1057-1066, 2009.

PAULY, C.; SPRING, P.; O’DOHERTY, J.V. et al. Performances, meat quality and boar taint of castrates and entire male pigs fed a standard and a raw potato starch-enriched diet. Animal, v.2, p.1707-1715, 2008.

ROSTAGNO, H.S.; ALBINO, L.F.T.; DONZELE, J.L. et al. Tabelas brasileiras para aves e suínos: composição de alimentos e exigências nutricionais. 2.ed. Viçosa, MG: UFV, 2005. 186p.

SAMPAIO, C.A.P.; CRISTANI, J.; DUBIELA, J.A. et al. Avaliação do ambiente térmico em instalações para crescimento e terminação de suínos utilizando os índices de conforto térmico nas condições tropicais. Ciência Rural, v.34, p.785-790, 2004.

XUE, J.L.; DIAL, G.D.; PETTIGREW, J.E. Performance, carcass, and meat quality advantages of boars over barrow: a literature review. Swine Health and Production, v.5, p.21-28, 1997.

XUE, J.L.; DIAL, G.D.; SCHUITEMAN, J. et al. Evaluation of growth, carcass, and compound concentrations related to boar taint in boars and barrows. Swine Health and Production, v.3, p.155-160, 1995.

WANG, T.C.; FULLER, M.F. The optimum dietary amino acid pattern for growing pigs. 1. Experiments by amino acid deletion. British Journal of Nutrition, v.62, p.77-89, 1989.

WEILER, U.; CLAUS, R.; DEHNHARD, M. et al. Influence of the photoperiod and a light reverse program on metabolically active hormones and food intake in domestic pigs compared with a wild boar. Canadian Journal of Animal Science, v.76, p.531-539, 1996.

WOOD, J.D.; ENSER, M.; FISHER, A.V. et al. Fat deposition, fatty acid composition and meat quality: a review. Meat Science, v.78, p.343-358, 2008.

ZAMARATSKAIA, G.; ANDERSSON, H.K.; CHEN, G. et al. Effect of a gonadotropin-releasing hormone vaccine (Improvac ${ }^{\mathrm{TM}}$ ) on steroid hormones, boar taint compounds and performance in entire male pigs. Reproduction in Domestic Animals, v.43, p.351-359, 2008a.

ZAMARATSKAIA, G.; RYDHMER, L.; ANDERSSON, H.K. et al. Long-term effect of vaccination against gonadotropin-releasing hormone, using Improvac ${ }^{\mathrm{TM}}$, on hormonal profile and behaviour of male pigs. Animal Reproduction Science, v.108, p.37-48, 2008b. 